\title{
MINAT MASYARAKAT KOTA WATAMPONE UNTUK MENGGUNAKAN JASA PERBANKAN SYARIAH
}

\author{
Darwis \\ Dosen Program Studi Manajemen Keuangan Syariah \\ Sekolah Tinggi Agama Islam (STAIN) Pare-Pare \\ darwismuhsidin@stainparepare.ac.id
}

\section{Keywords: \\ attitute, subjective norm, interest, and Islamic Banks}

\section{Kata Kunci:}

Sikap, Norma Subyektif, Minat, dan Perbankan Syariah

\section{ABSTRACT}

This research is appliesthe concept of Martin Fishbein and Icek Ajzen in Theory of Reasoned Action. It aims to find out: (a). the attitute (Ab) of the communty toward the interest to use Islamic Banks' service;(b) the subjective norm (SN) of the communty in relation to the interest to use Islamic Banks' service; and (c) the interest (BI) of the communty in using Islamic Banks' service. This research was conducted at Watampone city, South Sulawesi province with 96 respondents as the research samples. The data were collected by using questionnaires, and analysed by using the Fishbein Analysis Method. The results reveal that, the attitude value $(A b)$ is 104 with positive category. Therefore, it can be interpreted that respondents have certainty and good evaluation on the characterictics of Islamic Banks, and there is a tendency to show positive attitude toward the interest to use Islamic Bank' service. Secondly; the subjective norm (SN) is 78 with positive category. This leads to an interpretation that the respondents' interest to use Islamic Banks' service is influenced by the opinion of other important people (reference). Finally, the interest value (BI) is 47.216 with positive category, which can be interpreted that the community is quite interested to use Islamic Banks' service.

\section{ABSTRAK}

Penelitian ini bertujuan mengetahui (1) sikap (Ab) masyarakat terhadap minat untuk menggunakan jasa perbankan syari'ah, (2) norma subyektif (SN) masyarakat terhadap minat untuk menggunakan jasa perbankan syari'ah, (3) minat (BI) masyarakat untuk menggunakan jasa perbankan syari'ah.Penelitian ini bersifat deskriptif. Penelitian dilakukan di kota Watampone Provinsi Sulawesi Selatan. Sampel yang diambil sebanyak 96 responden. Pengumpulan data dilakukan dengan observasi, kuesioner dan dokumentasi. Data dianalisis dengan Metode analisis Fishbein.Hasil penelitian menunjukkan bahwa nilai sikap $(\mathrm{Ab})$ adalah 104 dengan kategori positif yang diinterpretasikan bahwa responden memiliki keyakinan dan evaluasi baik terhadap atribut-atribut yang melekat pada perbankan syariah. Hal ini menimbulkan kecenderungan untuk bersikap positif terhadap minat untuk menggunakan jasa perbankan syariah, nilai norma subyektif (SN) adalah 78 dengan kategori positif yang diinterpretasikan bahwa minat responden untuk menggunakan jasa perbankan syariah dipengaruhi atau mempertimbangkan pendapat orang lain yang penting (referen), dan nilai minat (BI) adalah 47,216 dengan kategori positif yang diinterpretasikan bahwa masyarakat cukup berminat untuk berperilaku menggunakan jasa perbankan syariah. 
AL-MASHRAFIYAH: Jurnal Ekonomi, Keuangan dan Perbankan Syariah Volume 2, Nomor 1 April 2018

\section{PENDAHULUAN}

Sistem Perbankan Syari'ah Indonesia dimulai tahun 1992 dengan digulirkannya UU No. 7/1992 yang memungkinkan bank menjalankan operasional bisnisnya dengan sistem bagi hasil. Hingga tahun 1998 praktis bank syari'ah tidak berkembang. Baru setelah diluncurkan Dual Banking System melalui UU No. 10/1998, perbankan syari'ah mulai menggeliat naik.Hadirnya lembaga keuangan syari'ah merupakan media dan lahan kajian ekonomi secara praktis dan akademis.

"Cetak Biru Pengembangan Perbankan Syari'ah di Indonesia" memuat visi, misi dan sasaran pengembangan perbankan syari'ah yaitu pencapaian pangsa pasar perbankan syari'ah yang signifikan melalui pendalaman peran perbankan syari'ah dalam aktivitas keuangan regional, nasional dan internasional.

Hanya saja, meski sudah memasuki lebih dari satu dasa warsa sejak diperkenalkannya sistem perbankan syari'ah,ternyata sampai saat ini belum terjadiproses massif masyarakat untuk mempergunakanjasa perbankan syari'ah. Ketua Dewan Komisioner Otoritas Jasa Keuangan (OJK) Wimboh Santosomenyatakan dalam program "Keuangan Syariah Fair (KSF)" dalam rangka mengkampanyekan Aku Cinta Keuangan Syariah (ACKS) di Cibinong City Mall, Bogor pada tanggal 27-29 Oktober 2017, bahwa "Rasio aset bank syari'ah terhadaptotal perbankan yang ada di Indonesia sampai saat ini masih di angka 5\%". Ini tentu ironis untuk sebuah negara yang mayoritas penduduknya adalah muslim.

Fakta ini menunjukkan bahwa perbankan syari'ah belum optimal dalam meraih pasar konsumennya.Salah satu penyebabnya adalah kegagalan komunikasi atau sosialisasi kepada masyarakat karena tidak optimalnya strategi pemasaran (Burhanuddin, 2005).Perbankan syari'ah belum sepenuhnya memahami perilaku konsumennya. Salah satu cara untuk mengenal konsumen adalah dengan mengetahui sikap dan minat konsumen karena sikap dan minat akan berdampak pada perilakunya.

Untuk mengetahui minat masyarkat terhadap perbankan syariah antara lain dengan mengacu pada Teori Tindakan Beralasan (Theory of Reasoned Action) yang dikemukakan oleh Fishbein dan Ajzen (1980). Teori ini mendalilkan bahwa maksud/minat, yang dipandang sebagai antesenden langsung dari perilaku, ditentukan oleh komponen sikap atau pribadi, dan komponen normatif atau sosial (Engel et al,1995). Jadi, minat dipengaruhi oleh dua variabel yaitu variabel sikap dan variabel norma subyektif. Sikap adalah faktor yang berasal dari individu sedangkan norma subyektif merupakan faktor yang berasal dari luar individu. Atas dasar teori ini, dikatakan bahwa masyarakat berminat untuk menggunakan jasa perbankan syariah bila ia menganggap perilaku tersebut positif dan bila orang-orang disekitarnya tidak menghalangi ia berperilaku seperti itu.

Tanggapan masyarakat yang berupa minat pada perbankan syariah merupakan hal yang penting bagi bank syariah di kota Watampone. Dengan diketahuinya minat masyarakat maka informasi ini sangat berguna sebagai masukan bagi pengevaluasian strategi pemasaran perbankan syariah di kota Watampone.

Oleh karena itu, penelitian yang bertujuan untuk mendeteksi 'apakah masyarakat mempunyai niat/minat untuk menggunakan jasa perbankan syariah' perlu dilakukan. Sebab secara emosional, perbankan syariah dekat dengan masyarakat Indonesia yang sebagaian besar beragama Islam. Akan tetapi hal tersebut tidak "dilirik" oleh masyarakat. Mengapa masyarakat berperilaku seperti itu?

Penelitian ini bertujuan untuk mengetahui: (1) sikap (Ab) masyarakat untuk menggunakan jasa perbankan syari'ah. (2) norma subyektif (SN) masyarakat untuk menggunakan jasa perbankan syari'ah. (3) minat (BI) masyarakat untuk menggunakan jasa perbankan syari'ah. 
Darwis. Minat Masyarakat Kota Watampone...

\section{LANDASAN TEORI}

\section{a. Konsep Perilaku Konsumen}

Tujuan pemasaran adalah memenuhi kebutuhan dan keinginan konsumen dengan mempelajari berbagai hal yang berhubungan dengan perilaku konsumen.Para pemasar harus mempelajari keinginan, persepsi, preferensi dan perilaku belanja konsumen (Kotler, 2005).

Loudon dan Bitta (1988) mendefinisikan perilaku konsumen sebagai proses pengambilan keputusan dan aktivitas individu secara fisik yang dilibatkan dalam mengevaluasi, memperoleh, atau menggunakan barang dan jasa. Jadi perilaku konsumen bukan hanya dilihat dari apakah seseorang membeli atau tidak suatu produk, melainkan proses yang menyeluruh sejak dari mencari hingga menghentikan pemakaian suatu produk atau jasa.

Model-model penelitian perilaku konsumen pada umumnya dihubungkan dengan sikap dan minat (Kristianto, 2010). Salah satu teori yang bisa menerangkan hubungan sikap, minat, dan The Theory of Reasoned Action yang dikembangkan oleh Fishbein dan Ajzen (1980) dalam karyanya "Understanding Attitude and Predicting Social Behavior". Teori ini bukanlah satusatunya yang dipakai dalam riset pemasaran untuk memprediksi pilihan konsumen, namun model teori tersebut menggambarkan metodologi yang paling canggih (Dharmestha, 1992). Theory of Reasoned Action adalah model yang secara umum menjelaskan dan memprediksi tujuan berperilaku/behavioral intentions pada berbagai setting. Teori ini divisualisasikan dalam gambar berikut:

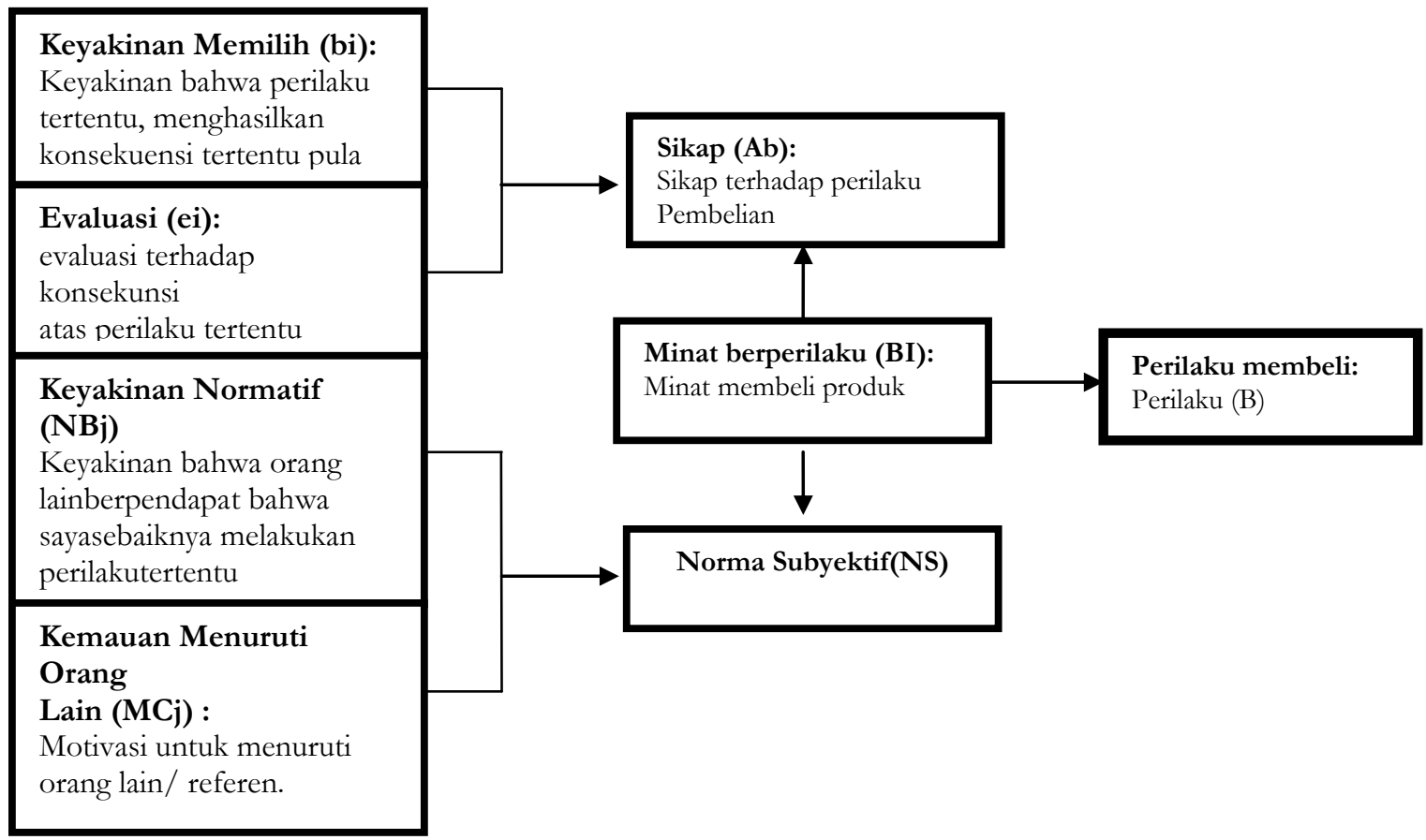

Gambar 1.Model Theory of Reasoned Action (Schiffman dan Kanuk, 2000)

Model ini menyatakan perilaku konsumen (B) terprediksi dari niat berperilaku (BI) yang terbentuk melalui suatu proses keputusan rasional. Niat berperilaku tersebut merupakan fungsi dari evaluasi keseluruhan tentang sikap terhadap perilaku $(\mathrm{Ab})$, ditambah keyakinan tentang pengharapan dari referen terhadap perilaku seperti itu yang kemudian ditimbang dengan motivasinya untuk menuruti pengharapan tersebut (SN). Sikap terhadap perilaku dibentuk dari kombinasi antara kekuatan (bi) dan evaluasi (ei) tentang keyakinan seseorang. Sementara itu norma subyektif merupakan produk keyakinan konsumen bahwa orang penting lain (referen) berpendapat ia seyogyanya atau tidak seyogyanya melaksanakan perilaku (NBj) 
dan motivasi dia untuk menuruti pendapat referen(MCj). Selain terhadap perilaku, model ini juga dapat dan seringkali diterapkan untuk mengukur sikap terhadap obyek tertentu.

Secara aplikatif penelitian konsumen yang mendasarkan pada teori Reasoned Action Model dari Fishbein dan Ajzen ini sudah banyak dilakukan, di antaranya Sigit (2006), Burhanuddin (2005), dan Albari (2004). Dalam penelitiannya, Sigit (2006) dan Burhanuddin (2005) melakukan analisis sampai dengan variabel minat untuk berperilaku.Hal ini berarti bahwa kedua orang tersebut mengganggap minat untuk berperilaku dapat dipakai untuk memprediksi perilaku konsumen yang diteliti. Sedangkan pada penelitian Albari (2004), perilaku beli konsumen diukur langsung dengan pernyataan responden melalui jawaban pada angket yang diedarkan dalam tenggang waktu kurang lebih satu bulan sesudah angket pertama.

Hipotesis penelitian yang diajukan adalah : (1) masyarakat mempunyai sikap (Ab) yang positif untuk menggunakan jasa perbankan syari'ah. (2) masyarakat mempunyai norma subyektif (SN) yang positif untuk menggunakan jasa perbankan syari'ah. (3) masyarakat mempunyai minat (BI) yang positif untuk menggunakan jasa perbankan syari'ah.

\section{METODE PENELITIAN}

\section{a. Populasi dan Sampel}

Populasi adalah masyarakat kota Watampone yang menjadi nasabah pada bank konvensional dan belum menjadi nasabah pada bank syariah dengan pertimbangan bahwa nasabah pada bank konvensional merupakan pasar yang potensial untuk memasarkan jasa perbankan syariah dan cukup dapat mengevaluasi atribut-atribut perbankan maupun referen yang menjadi acuan dalam memilih bank. Metode pengambilan sampel yang digunakan adalah purposive sampling, yaitu sampel dalam penelitian ditentukan dengan pertimbangan dan kriteriakriteria tertentu yang telah ditentukan. Sampel dipilih dari populasi dengan ketentuan (1) mengetahui lokasi kantor bank syariah di Watampone, (2) mengenal produk jasa tabungan perbankan syariah dan (3) berdomisili atau tinggal menetap di wilayah Kota Watampone.

\section{b. Variabel Penelitian Dan Defenisi Operasional}

Mengacu pada kajian teori dari model Reasoned Action Theory, maka untuk variabel penelitian ini di defenisikan sebagai berikut:

1) Keyakinan terhadap manfaat menggunakan jasa perbankan syariah (bi). Merupakan keyakinan konsumen berkenaan dengan manfaat dan konsekuensi yang diterima jika menggunakan jasa bank syari'ah. Variabel keyakinan diukur melalui indikator atribut-atribut perbankan syari'ah sesuai dengan syari'ah, rasa aman, pelayanan, sistem bagi hasil, dan aksebilitas lokasi. Pengukuran dilakukan dengan skala 1 (sangat tidak yakin) sampai 6 (sangat yakin).

2) Evaluasi terhadap manfaat menggunakan jasa perbankan syariah (ei).Merupakan penilaian konsumen terhadap konsekuensi apabila menggunakan jasa bank syari'ah. Diukur berdasarkan harapan konsumen pada perbankan syari'ah dengan indikator sesuai dengan syari'ah agama, rasa aman, pelayanan, sistem bagi hasil, dan aksebilitas lokasi. Pengukuran dilakukan dengan skala 1 (sangat tidak setuju) sampai 6 (sangat setuju).

3) Sikap untuk berperilaku (Ab). Merupakan ekspresi perasaan, yang mencerminkan apakah seseorang senang atau tidak senang, suka atau tidak suka, setuju atau tidak, positif atau negatif terhadap lembaga perbankan syariah. Variabel sikap diukur melalui perkalian skor keyakinan dan skor evaluasi.

4) Keyakinan normatif (NBj). Merupakan keyakinan konsumen akan pendapat kelompok referensinya. Diukur dengan indikator penggunaan jasa perbankan 
Darwis. Minat Masyarakat Kota Watampone...

syari'ah atas saran referen, yaitu keluarga, teman, tetangga dan toko agama. Pengukuran dilakukan denganskala 1 (sangat tidak yakin) sampai 6(sangat yakin)

5) Motivasi untuk menuruti pendapat orang lain (MCj). Merupakan kesediaan seseorang untuk menuruti anjuran pendapat referen yang mempengaruhinya. Diukur dengan indikator penggunaan jasa perbankan syari'ah karena menuruti saran keluarga, teman, tetangga dan toko agama. Pengukuran dilakukan dengan skala 1 (sangat tidak setuju) sampai 6 (sangat setuju).

6) Norma subyektif untuk menuruti pendapat referen (SN). Merupakan komponen yang berisikan keputusan seseorang untuk menggunakan jasa perbankan syari'ah yang terjadi karena adanya pengaruh sosial. Variabel norma subyektif diukur dengan mengalikan skor keyakinan normatif(NBj) dan skor motivasi(MCj).

7) Minat untuk berperilaku menggunakan jasa perbankan syari'ah (BI).Adalah kecenderungan konsumen untuk menggunakan jasa bank syari'ah karena adanya sikap yang positif dan norma subyektif yang diyakini. Keduanya (sikap dan norma subjektif) dijumlahkan setelah masing-masing dikalikan dengan bobot regresi yang ditentukan secara empiris.

\section{c. Metode Analisis Data}

Analisis data yang dilakukan didasarkan pada Reasoned Action Model dari Fishbein dan Ajzen (1980).Formula matematis dari model tersebut adalah:

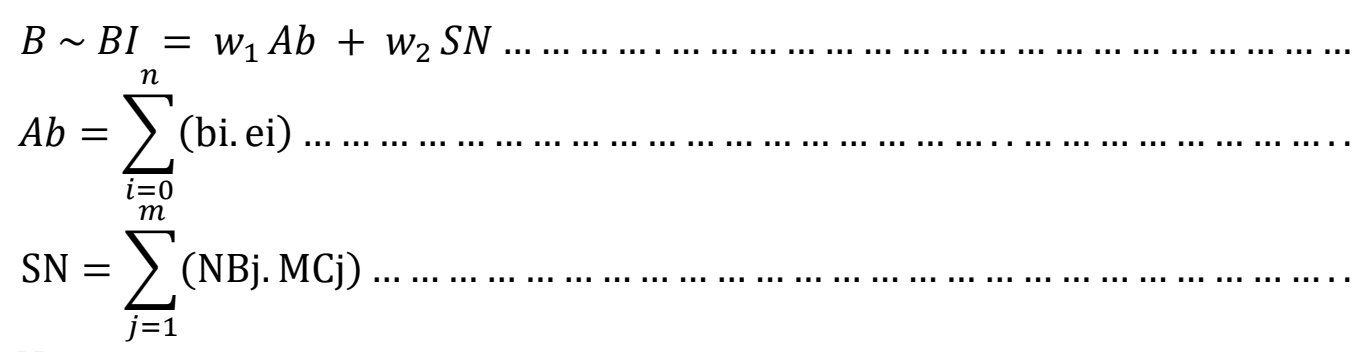

Keteranagan :
B = Perilaku aktual, dalam hal ini diproksimasi sama dengan BI
BI = Minat konsumen untuk melakukan perilaku tertentu
$\mathrm{Ab}=$ Sikap Konsumen terhadap perilaku tertentu.
bi = Tingkat keyakinan pada atribut tertentu (atribut ke-i)
ei $\quad=$ Evaluasi terhadap akibat atribut $\mathrm{i}$
$\mathrm{SN}=$ Norma subyektif individu terhadap pendapat/kehendak referen
$\mathrm{NBj}=$ Keyakinan normatif individu terhadap pendapat/kehendak referen
$\mathrm{MCj}=$ Motivasi untuk mengikuti pendapat/kehendak referen.
$\mathrm{n} / \mathrm{m} \quad=$ Banyaknya keyakinan/kelompok referen
$\mathrm{w}_{1} \mathrm{w}_{2} \quad=$ Bobot regresi yang ditentukan secara emperis.
tanda $\sim$ =Menunjukkan bahwa kedua variabel, B dan BI dapat berhubungan

Setelah hasil diperoleh untuk menginterpretasikan sikap (Ab), norma subyektif ( $\mathrm{SN}$ ), dan minat (BI) dalam kategori positif atau negatifdilakukan dengan skala interval sebagai berikut (Simamora, 2002):

Keteranagan:

$$
\text { Skala Interval }=\{\mathrm{a}(\mathrm{m}-\mathrm{n})\} / \mathrm{b}
$$
$\mathrm{a}=$ jumlah atribut
$\mathrm{m}=$ skor tertinggi yang mungkin terjadi
$\mathrm{n}=$ skor terendah yang mungkin terjadi
$\mathrm{b}=$ jumlah skala penilaian yang ingin dibentuk 


\section{HASIL DAN PEMBAHASAN}

Berdasarkan kuisioner yang telah diajukan kepada 96 responden diperoleh data responden paling banyak berusia 30-40 tahun sebanyak 31 orang dan didominasi oleh laki-laki sebanyak 68 orang. Dilihat dari jenis pendidikan terbanyak responden berpendidikan SMU/SMK sebanyak 52 orang dengan pekerjaan responden umumnya bekerja disektor Wiraswasta sebanyak 32 orang. Dari keyakinan responden umumnya adalah Muslim dengan persentase $68 \%$ atau 92 orang dan lebih banyak kurang memahami operasional perbankan syariah dengan persentase $50 \%$ atau 48 orang. Hasil penelitian terhadap variabel yang diterapkan dalam penelitian sebagai berikut :

Tabel 1. Keyakinan Terhadap Manfaat Menggunakan Jasa Perbankan Syariah(bi)

\begin{tabular}{lcccccc}
\hline Keterangan & bi1 & bi2 & bi3 & bi4 & bi5 & Rata-rata bi \\
\hline Keyakinan & 4,58 & 4,19 & 4,4 & 4,17 & 4,7 & 4,41 \\
Kategori & Kuat & Kuat & Kuat & Kuat & Kuat & Kuat \\
\hline
\end{tabular}

Sumber: Data primer diolah, 2017

Tabel 2. Evaluasi Terhadap Manfaat Menggunakan Jasa Perbankan Syariah(ei)

\begin{tabular}{lcccccc}
\hline Keterangan & ei1 & ei2 & ei3 & ei4 & ei5 & Rata-rata ei \\
\hline Evaluasi & 4,8 & 4,7 & 4,8 & 4,4 & 4,7 & 4,67 \\
Kategori & Kuat & Kuat & Kuat & Kuat & Kuat & Kuat \\
\hline
\end{tabular}

Sumber: Data primer diolah, 2017

Tabel 3. Keyakinan Normatif Terhadap Pendapat Referen(NBj)

\begin{tabular}{lccccc}
\hline Keterangan & NBj1 & NBj2 & NBj3 & NBj4 & Rata-rata NBj \\
\hline Key Normatif & 4,6 & 4,3 & 3,7 & 4,6 & 4,3 \\
Kategori & Kuat & Kuat & Cukup & Kuat & Kuat \\
\hline
\end{tabular}

Sumber: Data primer diolah, 2017

Tabel 4. Motivasi Untuk Menuruti Pendapat Referen(MCj)

\begin{tabular}{lccccc}
\hline Keterangan & $\mathrm{MCj} 1$ & $\mathrm{MCj} 2$ & $\mathrm{MCj} 3$ & $\mathrm{MCj} 4$ & Rata-rata MCj \\
\hline Motivasi & 4,7 & 4,5 & 4,1 & 4,6 & 4,4 \\
Kategori & Kuat & Kuat & Kuat & Kuat & Kuat \\
\hline
\end{tabular}

Sumber: Data primer diolah, 2017

\section{a. Menghitung Variabel Sikap untuk Berperilaku (Ab).}

Dalam penelitian ini variabel kepercayaan (bi) terdiri dari 5 sub variabel dan variabel evaluasi (ei) terdiri dari 5 sub variabel. Secara operasional matematis:

$$
\begin{aligned}
& \mathrm{Ab}=(\mathrm{bi} 1)(\mathrm{ei} 1)+(\mathrm{bi} 2)(\mathrm{ei} 2)+(\mathrm{bi} 3)(\mathrm{ei} 3)+(\mathrm{bi} 4)(\mathrm{ei} 4)+(\mathrm{bi} 5)(\mathrm{ei} 5) \\
& \mathrm{Ab}=(4,58)(4,8)+(4,19)(4,7)+(4,4)(4,8)+(4,17)(4,4)+(4,7)(4,7) \\
& \mathrm{Ab}=21,9+19,7+21,1+18,4+22 \\
& \mathrm{Ab}=104
\end{aligned}
$$

Dari hasil perhitungan dapat diketahui besarnya indeks sikap konsumen (Ab) adalah sebesar 104.Jika dibandingkan dengan tabel interpretasi nilai sikap maka nilai 104 berada pada skala ke-2 dengan kategori positif.Yang diinterperetasikan responden memiliki keyakinan dan evaluasi baik terhadap atribut-atribut yang melekat pada perbankan syariah. 
Darwis. Minat Masyarakat Kota Watampone...

Hasil analisis hipotesis pertama, menunjukkan bahwa arah sikap masyarakat kota Watampone terhadap minat untuk menggunakan jasa perbankan syariah adalah positif, hipotesis telah terbukti benar. Terbentuknya sikap positif karena masyarakat menilai atributatribut yang melekat pada perbankan syariah telah sesuai dengan keinginan mereka sehingga responden berkeyakinan manfaat yang diperoleh jika berperilaku menggunakan jasa perbankan syariah.

Dalam theory Reasoned Action variabel Sikap dibentuk dari kombinasi antara kekuatan(bi) dan evaluasi(ei) tentang keyakinan penting seseorang. Sehingga terjadinya penguatan sikap ke arah positif dengan dicapainya penilaian terhadap manfaat yang tinggi atau semakin baik/tinggi keyakinan konsumen. Jika diartikan dalam penelitian ini semakin positif sikap masyarakat terhadap bank syariah, maka semakin tinggi minat masyarakat untuk menggunakan jasa perbankan syariah.

\section{b. Menghitung Variabel Norma Subyekti (SN)}

Dalam penelitian ini variabel kepercayaan Normatif $(\mathrm{NBj})$ terdiri dari 4 sub variabel dan variabel motivasi $(\mathrm{MCj})$ terdiri dari 4 sub variabel. Dengan demikian secara operasional matematis menjadi sebagai berikut:

$$
\begin{aligned}
\mathrm{SN} & =(\mathrm{NBj} 1)(\mathrm{MCj} 1)+(\mathrm{NBj})(\mathrm{MCj} 2)+(\mathrm{NBj} 3)(\mathrm{MCj} 3)+(\mathrm{NBj} 4)(\mathrm{MCj} 4) \\
& =(4,6)(4,7)+(4,3)(4,5)+(3,7)(4,1)+(4,6)(4,6) \\
& =21,62+19,35+15,17+21,16 \\
& =78
\end{aligned}
$$

Dari hasil perhitungan diketahui besarnya indeks norma subyektif konsumen (SN) adalah sebesar 78. Jika dibandingkan dengan tabel interpretasi nilai norma subyektif maka nilai 78 berada pada skala ke-2 dengan kategori positif.Yang diinterpretasikan minat responden untuk berperilaku menggunakan jasa perbankan syariah dipengaruhi atau mempertimbangkan pendapat orang lain (referen).

Hasil analisis hipotesis kedua, menunjukkan bahwa norma subyektif masyarakat kota Watampone adalah positif, hipotesis telah terbukti benar. Terbentuknya norma subyektif ke arah positif karena masyarakat meyakini baik gagasan referen dan termotivasi untuk mengikuti gagasan tersebut.

Dalam theory Reasoned Action variabel keyakinan normatif (NBj) dan motivasi (MCj) berbanding lurus membentuk norma subyektif. Semakin tinggi nilai norma subyektif, maka konsumen semakin setuju untuk mengikuti referen dalam berperilaku dan semakin rendah nilai norma subyektif maka konsumen tidak setuju untuk mengikuti saran dari referen. Jika diartikan dalam penelitian ini semakin positif norma subyektif masyarakat, maka semakin tinggi minat responden untuk menggunakan jasa perbankan syariah.

\section{c. Menghitung Variabel Minat (BI)}

Untuk menghitung BI pertama-tama menentukan bobot secara agregat yang mencerminkan kontribusi relatif dari Sikap (Ab) sebagai W1, dan Norma Subyektif (SN) sebagai W2. Nilai WI dan W2 diperoleh dengan bantuan program SPSS.Menghitung indeks minat konsumen berdasarkan formula dari Fishbein dan Azjen, sebagai berikut:

$$
\begin{aligned}
\mathrm{B} \sim \mathrm{BI} & =\mathrm{w}_{1} \mathrm{Ab}+\mathrm{w}_{2} \mathrm{SN} \\
& =0,025(104)+0,572(78) \\
& =2,6+44,616 \\
& =47,216
\end{aligned}
$$

Berdasarkan hasil perhitungan menunjukkan nilai variabel minat sebesar 47,216. Jika dibandingkan dengan Tabel interpretasi nilai minat maka nilai 47,216 berada pada skala ke-2 
dengan kategori positif.Yang diinterpretasikan responden berminat untuk berperilaku menggunakan jasa perbankan syariah. Terbentuknya minat ke arah positif sehingga hipotesis telah terbukti benarkarena masyarakat meyakini secara kuat terhadap manfaat dari atributatribut yang melekat pada perbankan syariah dan menganggap perilaku tersebut positif serta masyarakat juga mempunyai persepsi kuat tentang keberadaan orang lain yang penting (referen) tentang gagasan yang menghendaki masyarakat untuk berperilaku menggunakan jasa perbankan syariah.

Dalam theory Reasoned Action terbentuknya minat seseorang ditentukan oleh hasil interaksi antara keberadaan sikap dan norma subyektif. Dengan demikian minat yang tinggi dapat dicapai dengan semakin positifnya sikap serta semakin kuatnya pengaruh referen.Jika diartikan dalam penelitian ini semakin positif sikap dan norma subyektif masyarakat terhadap bank syariah, maka semakin tinggi minat masyarakat tersebut untuk menggunakan jasa perbankan syariah, dan semakin positif minat masyarakat untuk menggunakan jasa perbankan syariah, maka dapat diprediksi masyarakat akan berperilaku untuk menggunakan jasa perbankan syariah.

\section{PENUTUP}

\section{a. Simpulan}

Berdasarkan hasil analisis serta pembahasannya maka dapat disimpulkan bahwa: Masyarakat kota Watampone mempunyai sikap ke arah positif terhadap minat untuk menggunakan jasa perbankan syariah berdasarkan penilaian pada atribut-atribut yang diteliti yaitu berdasarkan syariah, rasa aman, pelayanan, sistem bagi hasil dan aksebilitas lokasi. Masyarakat kota Watampone mempunyai norma subyektf ke arah positif untuk menggunakan jasa perbankan syariah, yaitu menuruti pendapat referen (keluarga, teman, tetangga dan tokoh agama). Masyarakat kota Watampone mempunyai minat cenderung ke arah positif untuk menggunakan jasa perbankan syariah.

\section{b. Saran}

Diharapkan perbankan syariah mampu meningkatkan atribut-atribut yang menonjol pada perbankan syariah guna mendapatkan sikap yang lebih bail dibenak konsumen.Pengaruh orang lain yang penting (referen) cukup kuat dalam proses pengambilan keputusan responden sehingga pihak perbankan syariah harus selalu meningkatkan pelayanan yang akan memberikan rasa puas terhadap konsumen sehingga akan muncul multiplier effect bagi konsumen lainnya. Sosialiasi perbankan syariah perlu ditingkatkan agar masyarakat dapat lebih paham tentang jasa bank syariah.

\section{DAFTAR PUSTAKA}

Albari, dan Liriswati, Anita (2004). Analisis Minat Beli Konsumen Sabun Cair Lux di Yogyakarta di Tinjau dari Pengarub Sikapnya dan Norma Subyektif.Jurnal Siasat Bisnis. No. 9 Vol. 2.

Ascarya (2008). Akad \& Produk Bank Syariah.RajaGrafindo Persada. Jakarta.

Burhanudin, Erwin, dan Ngaini, SN (2005). Analisis minat konsumen untuk bertransaksi pada perbankan syari'ah di kota Yogyakarta. Sinergi Jurnal Kajian Bisnis dan Manajemen.Edisi Khusus on Marketing.

Dharmmesta, Bayu Swasta (1992). Riset Tentang Minat dan Perilaku Konsumen: Sebuab catatan dan tantangan bagi peneliti yang mengacu pada "Theory of Reasoned Action". JEBI.No. 1 Tahun VII 1992.

Djarwanto, Pangestu S (1996). Statistik. Induktif. Cetakan ketiga.BPFE.Yogyakarta.

Engel, James F, Roger D. Blackwell, Miniard, Paul W(1995). Perilaku Konsumen.Edisi keenam. Binarupa Aksara. Jakarta 
Darwis. Minat Masyarakat Kota Watampone...

Fishbein, Martin and Ajzen, Icek (1980).Understanding Attitudes and Predicting Social Behavior. Englewood Cliffs, NJ: Prentice-Hall, Inc.

Kotler, Philip (2005). Manajemen Pemasaran.Edisi kesebelas.PT. Indeks kelompok Gramedia. Jakarta

Kristianto, Paulus Lilik(2010). Psikologi Pemasaran. Edisi pertama. Center For Academic Publishing Service. Yogyakarta

Loudon, D.L and Della, Bitta, A.J(1988). Consumer Behavior: Concept and Applications, Third Edition, McGraw-Hill Book. Co. New York

Schiffman, Leon G, dan Leslie Lazar Kanuk (2000). Consumer Behavior, $7^{\text {th }}$ ed. Prentice Hall International, Inc. New Jersey. USA

Setiadi, Nugroho, J (2003). Perilaku konsumen.Kencana. Jakarta.

Sigit, Murwanto. 2006. Pengarub Sikap dan Norma Subyektif Terbadap Minat Beli Mahasiswa. Jurnal Siasat Bisnis. Vol. 11 No.1. 